\title{
Over-expression of Bcl-2 against Pteris semipinnata L-induced apoptosis of human colon cancer cells via a NF-kappa B-related pathway
}

\author{
G. G. Chen, N.-C. Liang, J. F. Y. Lee, U. P. F. Chan, S. H. Wang, B. C. S. Leung and K. L. Leung
}

Department of Surgery (G. G. Chen, J. F. Y. Lee, U. P. F. Chan, B. C. S. Leung, K. L. Leung) and Sir Y.K. Pao Center for Cancer (G. G. Chen, B. C. S. Leung), Prince of Wales Hospital, The Chinese University of Hong Kong, Shatin, NT, Hong Kong; Institute of Biochemistry and Molecular Biology, Guangdong Medical College, Zhanjiang, Guangdong, People's Republic of China (N.-C. Liang); Department of Internal Medicine, Medical School, University of Michigan, Ann Arbor, MI, USA (S. H. Wang)

Ent-11 $\alpha$-hydroxy-15-oxo-kaur-16-en-19-oic-acid (5F), an antitumor component, is a chemical compound isolated from Pteris semipinnata $L(P s L)$, a Chinese traditional herb. We examined whether $5 \mathrm{~F}$ could affect apoptosis in human colon cancer HT-29 cells, and test whether and how the over-expression of $\mathrm{Bcl}-2$ and $\mathrm{Bcl}-\mathrm{xL}$ could offset the effect of $5 F$ on cell growth. The result demonstrated that $5 \mathrm{~F}$ significantly induced apoptosis of HT-29, as shown by MTT assay and DNA fragmentation measurement. Treatment of HT-29 with $5 \mathrm{~F}$ increased both p38 and iNOS levels, suggesting these two molecules may contribute to the apoptotic effect of $5 \mathrm{~F}$. Over-expression of $\mathrm{Bcl}-2$ or $\mathrm{Bcl}-\mathrm{xL}$ attenuated the increase of p38 and iNOS induced by $5 \mathrm{~F}$. The cells with $\mathrm{Bcl}-2$ or Bcl-xL overexpression showed an elevation of nuclear factor kappa B (NF-kappa B) activity, accompanying a significant reduction of $5 \mathrm{~F}$-induced apoptosis. Furthermore, inhibition of NF-kappa B by IkB $\alpha$ SR, which is a powerful inhibitor of NF-kappa B, restored the ability of $5 \mathrm{~F}$ to induce apoptosis in the cells transfected with Bcl-2. These data strongly indicated that the apoptotic effect of $5 \mathrm{~F}$ on HT29 was closely associated with the activity of NF-kappa $\mathrm{B}$, which was up-regulated by $\mathrm{Bcl}-2$ and $\mathrm{Bcl}-\mathrm{xL}$. In conclusion, 5F induced apoptosis in HT-29 cells and this apoptotic effect was associated with the high level of p38 and iNOS expression. The apoptotic effect of $5 \mathrm{~F}$ could be significantly offset by over-expression of either Bcl2 or $\mathrm{Bcl}-\mathrm{xL}$. Bcl-2, and to the less extent, $\mathrm{Bcl}-\mathrm{xL}$, were able to increase the activity of NF-kappa B, which was a known anti-apoptotic molecule in human colon cancer cells.

Keywords: apoptosis; Bcl-2; colon cancer; nuclear factor kappa B; Pteris semipinnata.

Correspondence to: George G. Chen, Department of Surgery, Prince of Wales Hospital, The Chinese University of Hong Kong, Shatin, NT, Hong Kong. Tel: 8522632 3934; Fax: 8522645 0605; e-mail: gchen@cuhk.edu.hk

\section{Introduction}

Pteris semipinnata $\mathrm{L}(\mathrm{PsL})$ is a Chinese traditional herb, which has been used to treat variety of inflammatory conditions such as hepatitis, enteritis and snake bite. ${ }^{1}$ Recently, several chemical compounds have been identified from the ethanolic extract of the PsL. Some of these compounds are able to inhibit the growth of tumor cells, including gastric adenocarcinoma cells (MGC-803), lung adenocarcinoma cells (SPC-A-1), human promyelocytic leukemia cells (HL-60), nasopharyngeal carcinoma cells (CNE-2Z), and liver adenocarcinoma cells (BEL-7402, HepG2). ${ }^{2,3}$ Further studies reveal that PsL-induced cell arrest is associated with reduced DNA topoisomerase, ${ }^{1}$ abnormal activation of mitogen activated protein kinase, ${ }^{4}$ decreased $\mathrm{Bcl}-2$ expression and high levels of Bax, c-Foc and c-Jun. ${ }^{5}$ However, the effect of PsL on human colon cancer cells has not yet been investigated.

Nuclear factor kappa B (NF-kappa B), a redox-sensitive transcription factor, is regulated by various apoptotic stimuli or inhibitors. A number of reports have shown that NF-kappa B is inhibited by apoptosis-inducing agents in human colon cancer cells. ${ }^{6-8}$ Like Bcl-2 and Bcl-xL, NFkappa $\mathrm{B}$ itself may serve as a pro-survival agent in various circumstances. ${ }^{9}$ The activation of NF-kappa B is known to induce the expression of $\mathrm{Bcl}-2$ and $\mathrm{Bcl}-\mathrm{xL} .{ }^{10-14}$ Inducible loss of NF-kappa B activity is associated with the downregulation of anti-apoptotic $\mathrm{Bcl}-2$ family members and the occurrence of apoptosis. Furthermore, the promoter regions of both $\mathrm{Bcl}-2$ and $\mathrm{Bcl}-\mathrm{xL}$ genes contain binding sites for NF-kappa B. ${ }^{13-15}$ On the other hand, $\mathrm{Bcl}-2$ can also stimulate or restore NF-kappa B activity. ${ }^{16,17}$

In the present experiment, we examined whether ent$11 \alpha$-hydroxy-15-oxo-kaur-16-en-19-oic-acid (5F), an effective antitumor component from PsL, ${ }^{1-5}$ could affect apoptosis in human colon cancer cells. In order to test whether and how the over-expression of $\mathrm{Bcl}-2$ and $\mathrm{Bcl}-\mathrm{xL}$ 
offsets the effect of PsL on cell growth, we transfected human colon cancer cells with either $\mathrm{Bcl}-2$ or $\mathrm{Bcl}-\mathrm{xL}$ gene.

\section{Materials and methods}

\section{Cell culture}

\begin{abstract}
A human colorectal cancer cell line, HT-29, was purchased from American Type Culture Collection (Rockville, Maryland), and cultured in RPMI 1640 medium (GIBCO BRL, Grand Island, New York) containing 10\% heatinactivated fetal bovine serum and antibiotics. Cells were treated with either $5 \mathrm{~F}$ or 7 -hydroxystaurosporine (UCN01 ) at concentrations indicated. $5 \mathrm{~F}$ was prepared as previous description. ${ }^{2-4} \mathrm{UCN}-01$ was kindly provided by the National Cancer Institute (Rockville, MD).
\end{abstract}

\section{Quantitation of cell death and apoptosis}

An MTT [3-(4,5-dimethylthiazol-2-yl)-2,5-diphenyltetrazolium bromide] assay was used to quantify cell death/viability. Cell death was also determined by DNA fragmentation assay kit (Roche Molecular Biochemicals, Mannheim, Germany), which measures apoptotic cell death by detection of BrdU-labled DNA fragments in the cytoplasm of affected cells. Briefly, DNA fragments in the cytoplasm were labeled with BrdU. After the BrdUlabeled DNA fragments were then isolated from the cells using the solutions provided by the kit, the BrdU-labeled DNA fragments were then detected using an enzymelinked immunosorbent assay (ELISA) method. The entire assay was performed according to the manufacturer's instruction. Appearance of DNA fragments has been considered as a hallmark of apoptosis. Apoptotic cells were also evaluated by TUNEL assay using an APO-Direct Flow Cytometry Kit from Chemicon (Temecula, CA). The TUNEL assay was performed according to the kit instruction from Chemicon.

\section{DNA transfection}

Stable transfection was performed using cationic lipid reagent, LipofectAMINE (Life Technologies, Rockville, Maryland). The experiment was carried out according to the manufacturer's instruction. HT-29 cells (80-85\% confluence) were transfected with $500 \mathrm{ng}$ of plasmid DNA in serum-free conditions. After the cells were incubated for 6 hours in serum-free medium containing DNA and LipofectAMINE, an equal volume of growth medium containing 20\% serum was then added without removing the transfection mixture. The supernatant was changed with complete medium at 24 hours following the start of transfection. At 72 hours after transfection, the cells were passaged into the selective medium containing geneticin selective antibiotic, G418. The concentration of G418 for the selection was previously determined by dose-response assay. Positive stably-transfected cells were selected by G418 (0.4 mg/ml) after 2 months.

\section{Western blot analysis}

Cell samples were homogenized with ice-cold PBS and then lysed in a solution containing $8 \mathrm{M}$ urea, $0.1 \mathrm{M}$ $\mathrm{Na}_{2} \mathrm{H}_{2} \mathrm{PO}_{4}$ and $0.01 \mathrm{M}$ Tris-HCl. Supernatants were obtained after centrifugation at $10,000 \times \mathrm{g}$. Proteins were separated on $10 \%$ SDS-polyacrylamide gels. Proteins were then electrophoretically transferred from the gel onto nitrocellulose membranes and the membranes were blocked for 1 hour in PBS-Tween buffer containing 5\% dry milk powder (fat free) at room temperature. The membranes were then incubated with a primary antibody for 1 hour. After washing, the membranes were incubated with a secondary antibody, IgG-HRP (Santa Cruz Biotechnology, Santa Cruz, California). Finally, they were treated with the reagents in the chemiluminescent detection kit (ECL system, Amersham Pharmacia Biotech, Piscataway, New Jersey) according to the manufacturer's instructions. Anti-human actin antibody (Santa Cruz Biotechnology, Santa Cruz, California) was used to detect human actin, which was used as a control for equal loading. Anti-human antibodies: Bcl-2, Bcl-xL, Bid, p65, cyclooxygenase-2 (COX-2), inducible nitric oxide (iNOS) and p38 mitogenactivated protein kinase (p38 MAPK) were obtained from Santa Cruz Biotechnology (Santa Cruz, California). The densities of the protein bands corresponding to the size were determined with a GSP-700 scanner with Quantity One image software (Hercules, CA).

\section{Nuclear protein extraction and NF-kappa B activity assay}

Nuclear protein was isolated according the procedure described. ${ }^{18}$ Briefly, HT-29 cells were harvested, washed in PBS, and collected by centrifugation. The cell pellet was resuspended in $0.5 \mathrm{ml}$ of $10 \mathrm{mM}$ Tris- $\mathrm{HCl}(\mathrm{pH} 7.5) / 5$ $\mathrm{mM} \mathrm{MgCl}_{2} / 0.05 \%(\mathrm{v} / \mathrm{v})$ Triton X-100 and lysed with 20 strokes in a homogenizer. The homogenate was centrifuged at $10,000 \times \mathrm{g}$ for 15 minutes at $4^{\circ} \mathrm{C}$. The pellet was obtained. The nuclei pellet volume was estimated and the pellet was resuspended in an equal volume of $10 \mathrm{mM}$ Tris- $\mathrm{HCl}$ ( $\mathrm{pH} 7.4) / 5 \mathrm{mM} \mathrm{MgCl}_{2}$, followed by the addition of 1 nuclear pellet volume of $1 \mathrm{M} \mathrm{NaCl} / 10 \mathrm{mM}$ Tris- $\mathrm{HCl}$ ( $\mathrm{pH} 7.4) / 4 \mathrm{mM} \mathrm{MgCl}_{2}$. The lysing nucleus was left on ice for 30 minutes and then centrifuged at $10,000 \times \mathrm{g}$ for 15 minutes at $4^{\circ} \mathrm{C}$. The supernatant (nuclear extract) 
was removed and $80 \%$ glycerol was added so that the final glycerol concentration was $20 \%(\mathrm{v} / \mathrm{v})$. The concentration of the nuclear protein was determined. NF-kappa B activity was measured by an enzyme immunoassay kit from Oxford Biomedical Research (Oxford, MI), which employed an oligonucleotide containing the DNA binding NF-kappa B consensus sequence. If there is any NF-kappa $\mathrm{B}$ presented in the sample, it will specifically bind to the oligonucleotide coated on the plate and the DNA-bound NF-kappa B can be selectively recognized by the antibody to NF-kappa B subunit, p50 or p105.

\section{Inhibition of NF-kappa B}

A recombinant replication-deficient adenovirus, $\mathrm{Ad} 5 \mathrm{IkB}$, contains an $\mathrm{IkB}$ construct in which serines 32 and 36 are mutated to alanines, driven by the cytomegalovirus promoter-enhancer. This mutant IkB cannot be phosphorylated, and therefore irreversibly binds to NF-kappa B, preventing its activation. ${ }^{19,20} \mathrm{Ad} 5 \mathrm{IkB}$ (a generous gift from Dr. D Brenner) was used as previously described. ${ }^{20}$ The adenovirus, Ad5LacZ, which contains the Escherichia coli $\beta$-galactosidase gene, was used as a control. Both viruses were grown in 293 cells and purified as the previous description. ${ }^{20}$ For adenovirus infection, subconfluent cells $(\sim 80 \%)$ were infected with virus in serum-free medium at multiplicity of infection (MOI) of 10-500 for 12 hours. The free virus was then washed off and fresh media containing serum was added to the cells. The cells were cultured for another 12 hours before experiments.

\section{Statistical analysis}

All values were expressed as mean \pm standard error. Statistical comparisons were analyzed by the Student's $t$ test using InStat software (GraphPad Software, San Diego, California). A $P$-value of less than 0.05 was taken as statistically significant.

\section{Results}

\section{$5 \mathrm{~F}$ induced cell death in dose- and time-dependent manners}

5F induced HT-29 cell death in a dose-dependent manner between the concentrations of 1 and $100 \mathrm{mg} / \mathrm{L}$ (Figure $1 \mathrm{~A})$. At the concentration of $100 \mathrm{mg} / \mathrm{L}$, over $95 \%$ of the cells were dead after 48 -hour treatment. The effect of $5 \mathrm{~F}$ was also found in a time-dependent fashion (Figure 1B). Compared with 24-hour treatment with 10 $\mathrm{mg} / \mathrm{L}$ of $5 \mathrm{~F}$, the cell death was gradually increased to about 3.5 folds and 5.1 folds after 48 -hour and 72-hour treat-
Figure 1. Cell death induced by $5 \mathrm{~F}$ and UCN-01. After HT-29 cells were treated by $1-100 \mathrm{mg} / \mathrm{L}$ of $5 \mathrm{~F}$ or $50-200 \mathrm{nM}$ of UCN01 for 48 hours ( $A$ and $C$ ), the cell was harvested and the MTT assay was performed to measure cell death. For the time-course study, the cell was treated with either $10 \mathrm{mg} / \mathrm{L}$ of $5 \mathrm{~F}$ or $100 \mathrm{nM}$ of UCN-01 for 24, 48 and 72 hours (B and D). At the end of the time point, the cell death was measured by MTT assay. Control cells were treated with vehicle only. The result of MTT was expressed as Cell Death Index, which was calculated by the following formula: [1-absorbance(test well-background)/absorbance (controlbackground)] $\times 100 \%$. Each experiment was repeated at least 3 times.
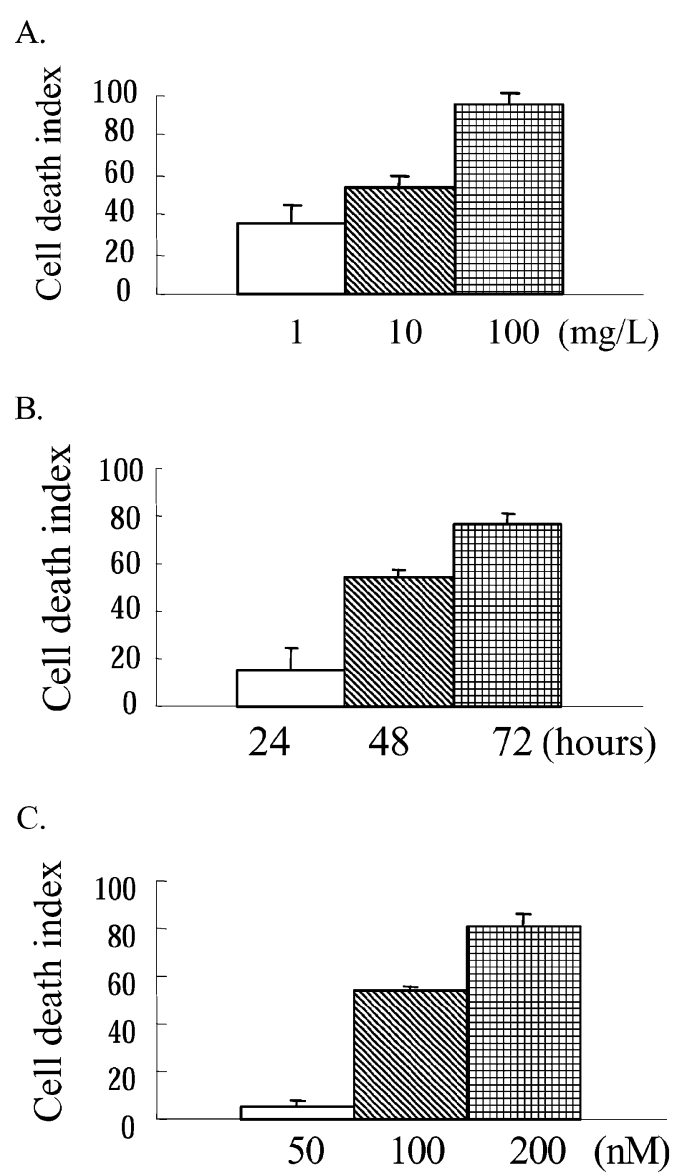

D.

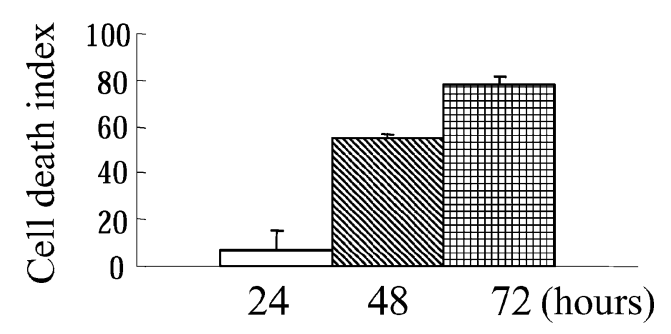

ments with $5 \mathrm{~F}$ respectively. Both the dose- and the timedependent manners were similar to the results obtained when the cells were treated with UCN-01 (Figures 1C and D). 


\section{$5 \mathrm{~F}$ upregulated the expression of p38 MAPK and iNOS but downregulated the levels of $\mathrm{Bcl}-2$ and $\mathrm{Bcl}-\mathrm{xL}$}

To understand how $5 \mathrm{~F}$ regulates cell death, we measured several cell death-related molecules in HT-29 cells treated with 5F. By Western blot analysis, we found that the expression of p38 MAPK and iNOS was much higher in the cells treated with $5 \mathrm{~F}$ than those treated with vehicle, whereas the levels of p65, Bcl-2 and $\mathrm{Bcl}-\mathrm{xL}$ were lower (Figure 2). The expression of COX-2 and other Bcl-2 family members such as Bid and Bcl-xs was not different between the treatment and the control (data not shown). The similar expression patterns of these molecules analyzed were also observed in the cells treated with UCN-01 (Figure 2). The alteration of p $38 \mathrm{MAPK}$, iNOS, Bcl-2 and $\mathrm{Bcl}-\mathrm{xL}$ could be occur as early 24 hours (data not shown), which predated the activation of caspase- 3 . Time course study showed that a slight increase in $32 \mathrm{kDa}$ caspase- 3 at 36 hours and the active caspase- $3(20 \mathrm{kDa})$ did not appear until 48 hours after $5 \mathrm{~F}$ treatment (Figure 3).

\section{Over-expression of Bcl-2 and Bcl-xL protected cell death induced by $5 \mathrm{~F}$}

To investigate how the over-expression of Bcl-2 and Bcl$\mathrm{xL}$ affects the cell death in HT-29 induced by 5F, we transfected HT-29 cells with Bcl-2, Bcl-xL, or pcDNA3.1 plasmids and the cells were named as HT-29/Bcl-2, HT29/Bcl-xL and HT-29/mock cells respectively. Positive clones were selected by G418 and the over-expression of $\mathrm{Bcl}-2$ or $\mathrm{Bcl}-\mathrm{xL}$ was confirmed using Western blot (Figure 4). In order to clarify whether the over-expression

Figure 2. Effect of $5 \mathrm{~F}$ and UCN-01 on the protein levels of $\mathrm{p} 38 \mathrm{MAPK}$, iNOS, Bcl-2 and Bcl-xL. HT-29 cells were treated with $10 \mathrm{mg} / \mathrm{L}$ of $5 \mathrm{~F}$ or $100 \mathrm{nM}$ of UNC-01 for 48 hours and then cell lysates were obtained for Western blot analysis of p38 MAPK (38 KDa), iNOS (130 KDa), p65 (65 KDa); Bcl-2 (28 KDa) and Bcl-xL (32 KDa). Actin protein (43 KDa), which is constitutively expressed, was used as a control. The densities of the protein bands corresponding to the size were determined and the relative amount of the target protein was shown as Expression Index, which was calculated by the formula: the density of the control (actin) band/ the density of the target band.

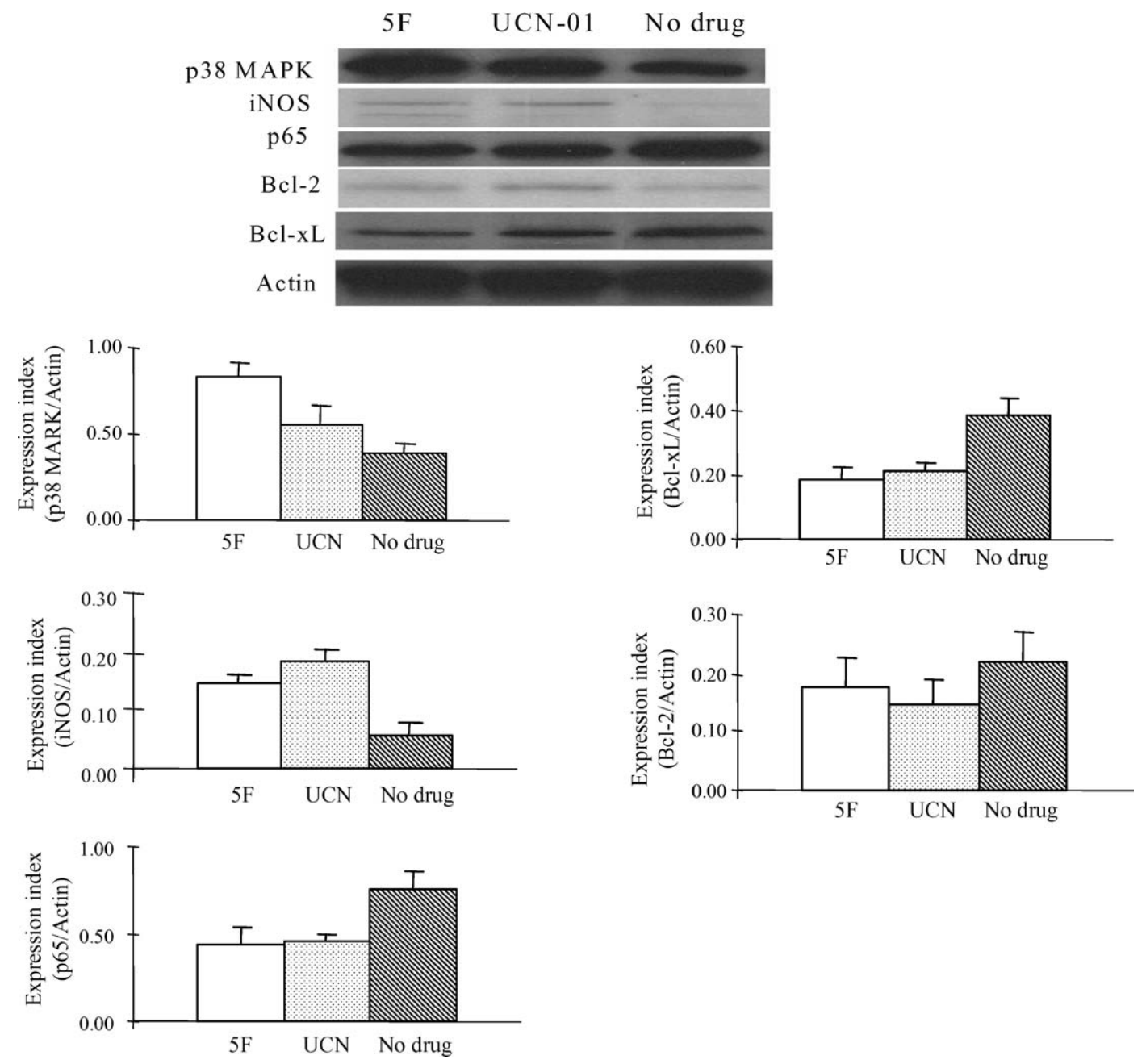


Figure 3. Time-course study of caspase-3 expression. HT-29 cells were treated with $10 \mathrm{mg} / \mathrm{L}$ of $5 \mathrm{~L}$ and cell lysates were obtained at 0 (without $5 \mathrm{~L}$ treatment), 24, 36, 48 and 60 hours for protein analysis. Detection of caspase-3 protein was performed using the ECL Western blotting detection system.

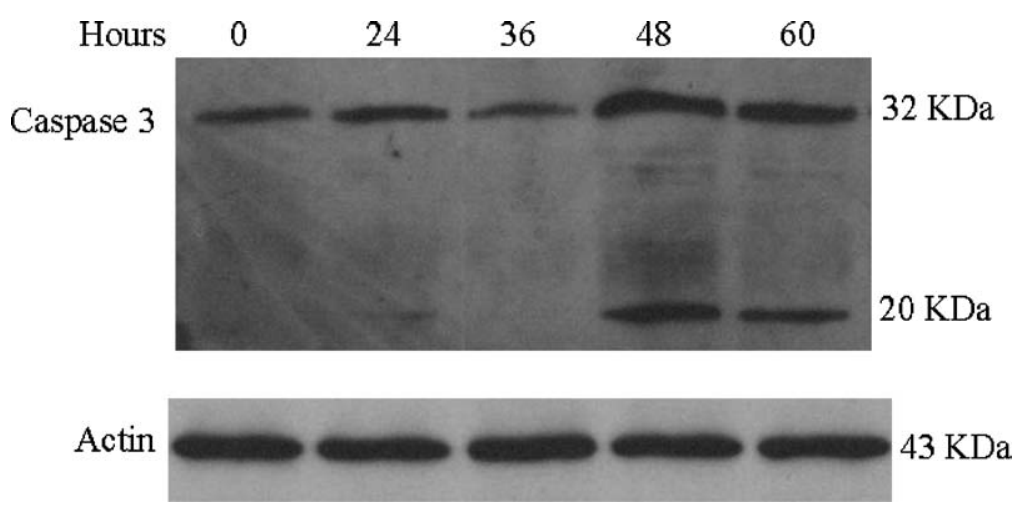

Figure 4. Over-expression of Bcl-2 and Bcl-xL in HT-29. After stable transfection, HT-29/Bcl-2 and HT-29/Bcl-xL cells were established. Cell lysates were isolated from the cells and Bcl-2 $(28$ $\mathrm{KDa})$ and $\mathrm{Bcl}-\mathrm{xL}(32 \mathrm{KDa})$ levels were determined by Western blot analysis. A: The cells transfected with $\mathrm{Bcl}-2$ or $\mathrm{Bcl}-\mathrm{xL}$ genes; $\mathrm{B}$ : The cells transfected with an empty vector.

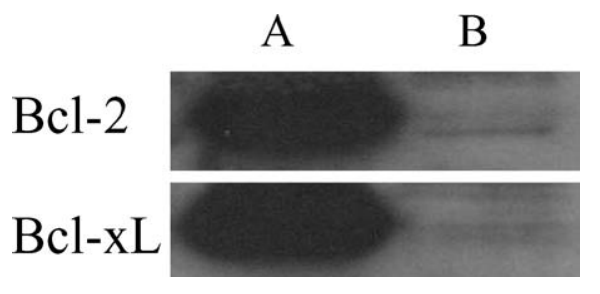

of $\mathrm{Bcl}-2$ or $\mathrm{Bcl}-\mathrm{xL}$ in HT-29 cells blocks the chemical induction of apoptosis, HT-29/Bcl-2, HT-29/Bcl-xL and HT-29/mock cells were treated with a known cell death inducer, UCN-01 (Figure 5). Following treatment, cell death was measured by MTT assay. The result showed that HT-29/Bcl-2 and HT-29/Bcl-xL cells had a significantly higher percentage of living cells compared to HT-29/mock cells (Figure 5A), indicating that the HT29/Bcl-2 and HT-29/Bcl-xL transfectants were functional. These cells were then treated with $10 \mathrm{mg} / \mathrm{L}$ of $5 \mathrm{~F}$ (Figure 5B). While HT-29/mock cells displayed marked death in response to $5 \mathrm{~F}$ treatment, $\mathrm{HT}-29 / \mathrm{Bcl}-2$ and $\mathrm{HT}-29 / \mathrm{Bcl}-$ $\mathrm{xL}$ cells showed approximately $95 \%$ and $90 \%$ protection from $5 \mathrm{~F}$-induced death respectively. The cell death induced by either $5 \mathrm{~F}$ or UCN-01 was mainly caused by apoptosis, as the similar result was obtained by DNA fragmentation assay (Figures $5 \mathrm{C}$ and D). The occurrence of DNA fragment is a typical Marker for apoptosis. Apoptosis was further confirmed by TUNEL assay (APO-Direct Flow Cytometry Kit, Chemicon, Temecula, CA). After 5F treatment, HT-29/Bcl-2 and HT-29/Bcl-xL cells exhibited only $1.51 \%$ and $0.25 \%$ of apoptotic cells while the control cells (without treatment or vector transfection only) showed average $82.46 \%$ of apoptotic cell death, sug- gesting that $5 \mathrm{~F}$ could offer $98-99 \%$ protection against the cytotoxic effect of $5 \mathrm{~F}$.

\section{Over-expression of $\mathrm{Bcl}-2$ and $\mathrm{Bcl}-\mathrm{xL}$ increased NF-kappa B activity}

NF-kappa B activity is known to be closely associated with $\mathrm{Bcl}-2$ and Bcl-xL expression. ${ }^{10-14,16,17}$ In order to determine how the over-expression of $\mathrm{Bcl}-2$ and $\mathrm{Bcl}-\mathrm{xL}$ affects the NF-kappa B activity in HT-29 cells treated either 5F or UCN-01, the cells transfected with either Bcl-2 or Bcl$\mathrm{xL}$ were incubated with $10 \mathrm{mg} / \mathrm{L}$ of $5 \mathrm{~F}, 100 \mathrm{nM}$ of UCN01 or vehicles. The nuclear protein was isolated after incubation. The cells transfected with an empty pcDNA3.1 vector and the cells without any transfection were used as controls. NF-kappa B activity was significantly higher in the cells with $\mathrm{Bcl}-2$ or $\mathrm{Bcl}-\mathrm{xL}$ (Figure 6). It appeared that Bcl-2 was more effective in raising NF-kappa B activity than Bcl-xL.

\section{Inhibition of NF-kappa B offsetted the protective effect offered by Bcl-2 and Bcl-xL}

Since the over-expression of $\mathrm{Bcl}-2$ and $\mathrm{Bcl}-\mathrm{xL}$ increased the activity of NF-kappa B and protected the cells from apoptosis induced by $5 \mathrm{~F}$ and $\mathrm{UCN}-01$, it would be interesting to know whether the inhibition of NF-kappa $\mathrm{B}$ activity could diminish the protective effect offered by Bcl-2 and Bcl-xL. A super-repressor of NF-kappa B activity $(\mathrm{Ad} 5 \mathrm{IkB})$, which is a mutated non-degradable $\mathrm{IkB} \alpha$ resistant to phosphorylation and degradation, was used to inhibit the activity of NF-Kappa B. Previous experiments have demonstrated that this super-repressor was capable of inhibiting the activity of NF-kappa B in HT-29 cells. HT-29/Bcl-2 cells regained their sensitivity to apoptosis induced by $5 \mathrm{~F}$ after being treated by $\mathrm{Ad} 5 \mathrm{IkB}$ (Figure 7A). 


\section{G. G. Chen et al.}

Figure 5. Protection of cell death induced by UCN-01 and $5 \mathrm{~F}$ with $\mathrm{Bcl}-2$ or $\mathrm{Bcl}-\mathrm{xL}$. HT-29 cells with extraneous genes $(\mathrm{Bcl}-2$ or $\mathrm{Bcl}-\mathrm{xL})$ or without were incubated with $10 \mathrm{mg} / \mathrm{L}$ of $5 \mathrm{~F}(\mathrm{~B}$ and $\mathrm{D})$, $100 \mathrm{nM}$ of UCN-01 (A and C) or vehicles for 48 hours. The cell death was measured by the MTT assay (A and B). The result of MTT was expressed as Cell Death Index (see Figure 1 for details). The cell apoptosis was determined by DNA fragmentation detection assay ( $C$ and $D$ ). DNA fragments from damaged cells were released into the culture supernatant and labeled by BrdU. The BrdU-labled DNA was quantified using a monoclonal antibody against BrdU. Each point represents a mean of three independent experiments with triplicate wells. The result of DNA fragmentation detection assay was expressed as Apoptotic Index, which was calculated by the following formula: [1-absorbance(test wellbackground)/absorbance (control-background)] $\times 100 \%$. \#NT: No (UNC-01 or 5F) treatment. ${ }^{* *} p<0.01,{ }^{*} p<0.05$ compared with the controls.

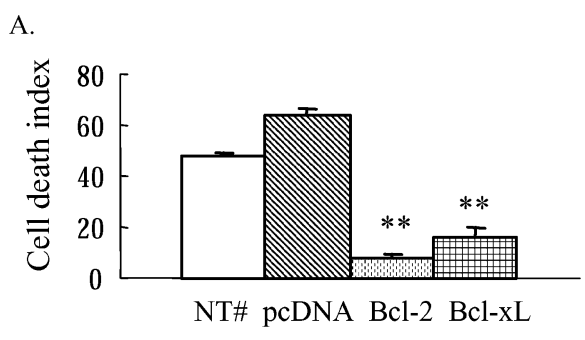

B.

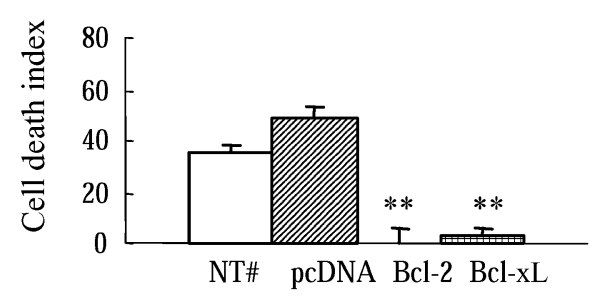

C.

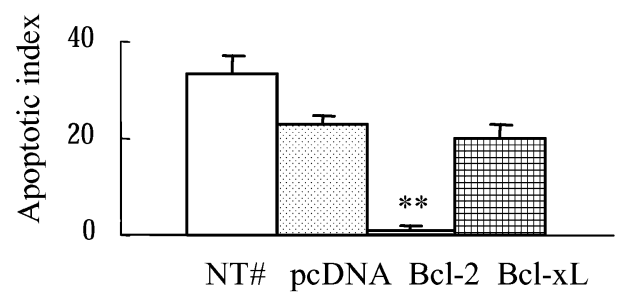

D.

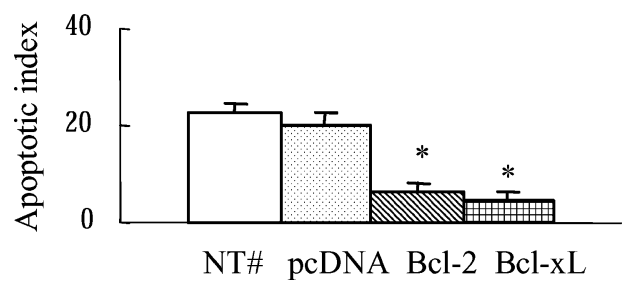

However, a significant portion of $\mathrm{HT}-29 / \mathrm{Bcl}-\mathrm{xL}$ cells was not protected after treated by Ad5IkB (Figure 7A), suggesting that $\mathrm{Bcl}-\mathrm{xL}$ could still function, to a certain degree, to protect the cells from death when the activity of
Figure 6. NF-kappa B activity in the cells with Bcl-2 and Bcl$\mathrm{xL}$ over-expression. HT-29 cell culture was the same as that described in Figure 4 and cells were with $10 \mathrm{mg} / \mathrm{L}$ of $5 \mathrm{~F}(\mathrm{~B}), 100$ $\mathrm{nM}$ of UCN-01 (A) or vehicles for 48 hours. After culture, the nuclear protein was isolated for the determination of NF-kappa B activity, which was measured by a commercially-available ELISA kit. Each point represents a mean of three independent experiments with triplicate wells. \#NT: No (UNC-01 or 5F) treatment. ${ }^{* *} p<0.01,{ }^{*} p<0.05$ compared with the controls.

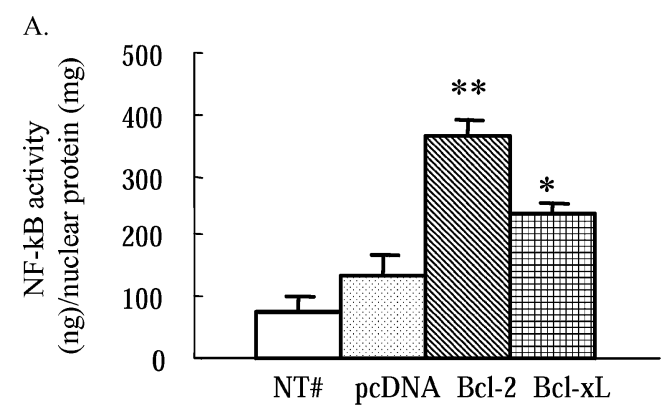

B.

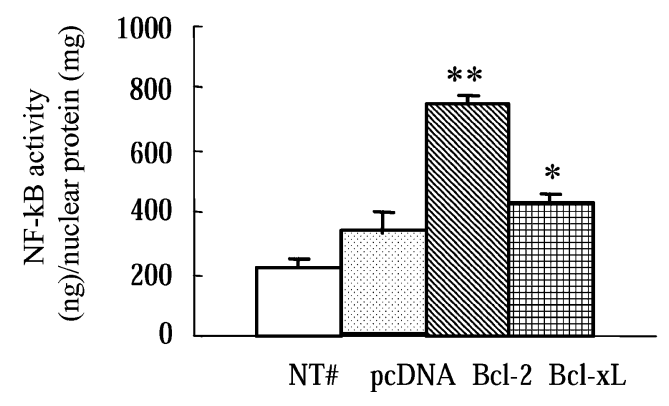

Figure 7. Attenuation of $\mathrm{Bcl}-2$ and $\mathrm{Bcl}-\mathrm{xL}$ protection by the inhibition of NF-kappa B activity. The cells were infected with either Ad5lkB or Ad5LacZ, as described in Methods. After the infection, the cells were stimulated with $5 \mathrm{~F} 10 \mathrm{mg} / \mathrm{L}$ of $5 \mathrm{~F}(\mathrm{~A}), 100 \mathrm{nM}$ of UNC-01 (B) or vehicle alone for 48 hours. The cell death was measured by the MTT assay. The result of MTT was expressed as Cell Death Index (see Figure 1 for details). \#NT: No (UNC-01 or $5 \mathrm{~F}$ ) treatment.

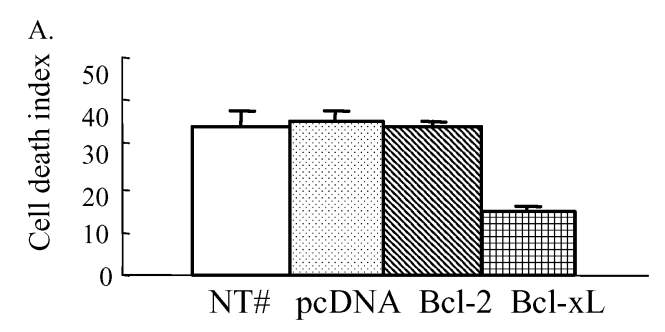

B.

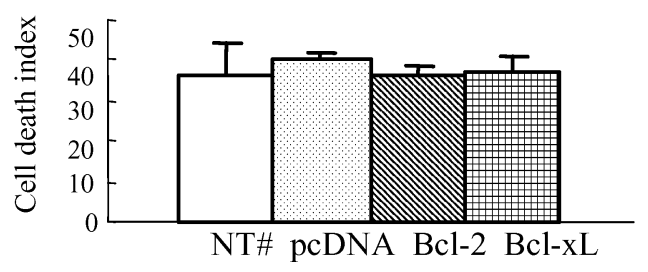


NF-kappa B was inhibited. Somewhat different from 5F, cell death induced by UCN-01 in both HT-29/Bcl-2 and HT-29/Bcl-xL cells were prevented when the cells were treated by Ad5IkB (Figure 7B), indicating that both Bcl2 and $\mathrm{Bcl}-\mathrm{xL}$ lost their anti-apoptotic effects when the activity of NF-kappa B was suppressed.

\section{Discussion}

Although 5F, a chemical component isolated from PsL, has been known to inhibit the growth of several types of tumor cells, ${ }^{1-5}$ the mechanism is not yet clear and its effect on human colon cancer cells has not yet been studied before. In the present study, we demonstrated that $5 \mathrm{~F}$ was able to induce cell death via an apoptotic pathway and in a similar manner to UCN-01. UCN-01 was originally identified as a more specific inhibitor of protein kinase $\mathrm{C}$ (PKC) than the parent compound staurosporine. ${ }^{21,22}$ However, the inhibition of PKC is unlike to be responsible for its effect on the cell growth arrest. UCN-01 showed the growthinhibitory effect against malignant cells, as demonstrated in the present and others' studies. ${ }^{23,24} \mathrm{UCN}-01$ is currently undergoing clinical evaluation as an antitumor drug in the United State and Japan. $5 \mathrm{~F}$ at the concentration of $10 \mathrm{mg} / \mathrm{L}$ seems to be able to achieve the same efficiency of UCN-01 at $100 \mathrm{nM}$, as both drugs at these concentrations induced a similar number of cell death and also they were able to generate very similar time-course curves. Therefore, by comparing $5 \mathrm{~F}$ with a well-known cell growth inhibitor, such as UCN-01, it will help us to evaluate whether $5 \mathrm{~F}$ can be considered to be an anti-cancer agent.

In the present study, we found that a number of molecules were altered at protein levels in human colon cancer cells treated by 5F. Both p38 MAPK and iNOS were increased by either $5 \mathrm{~F}$ or UCN-01 treatment. It is widely accepted that iNOS is a main enzyme responsible for a large amount of nitric oxide (NO) production. $\mathrm{NO}$ is apoptosis-inducer in a variety of human cells and has been a target for novel therapy in a number of malignant cells. For example, in human gastric cancer, NO contributes to the tumouricidal activity of 5-fluorouracil. ${ }^{25}$ In human colon cancer cells, NO generated by interferon-gamma and tumor necrosis factor alpha induces cell death. ${ }^{26} \mathrm{NO}$ donors, such as glyceryl trinitrate, are known to induce apoptosis via a pathway related to activating caspase cascade, increasing the expression of Fas and decreasing the expression of several inhibitors of apoptosis (IAPs). ${ }^{27}$ The production of NO is closely associated with p38 MAPK. p38 MAPK is involved in the generation of NO, at least, at two points. First, the p38 MAPK pathway can enhance $\mathrm{NO}$ production by increasing the intracellular concentration of the substrate for NO synthetase via stimulation of arginine transporter activity. ${ }^{28}$ Second, p38 MAPK activity is required for the increased gene expression of iNOS. ${ }^{29}$ In addition, activation of p38 MAPK is also involved in the NO-induced apoptosis by relaying NO signal to its down stream apoptotic molecules including p53, cytochrome $c$ and caspases. ${ }^{30,31}$ The increased p38 MAPK and NO levels are reported to participate cell death induced by UCN-01,23,32 which is in line with the current findings. Therefore, the result of increased iNOS and p38 MAPK is thought to contribute to the cell death induced by $5 \mathrm{~F}$.

NF-kappa B has recently emerged as a major player in a variety of human cancers mainly because of its ability to protect transformed cells from apoptosis. There is increasing evidence to support a role for NF-kappa B in tumorigenesis of colon cancer and to document that the inhibition of NF-kappa B suppresses the growth of colon cancer cells via an apoptotic pathway, $6,7,33,34$ which is impaired during colon cancer development. ${ }^{6,35}$ Dietary flavone dramatically reduced NF-kappa B activity, together with COX-2 levels. ${ }^{34}$ The reduction was displayed a high selectivity for the induction of apoptosis and of growth inhibition. The mechanism of $5 \mathrm{~F}$ on human colon cancer cells may be different from flavone, as it didn't change the COX-2 expression though it did reduce the activity of NF-Kappa B. We found that accompanying the decreased NF-kappa B activity by $5 \mathrm{~F}$ was the reduction of two anti-apoptotic Bcl-2 family members, Bcl-2 and Bcl$\mathrm{xL}$. The finding is not surprising, as both the promoter regions of $\mathrm{Bcl}-2$ and $\mathrm{Bcl}-\mathrm{xL}$ genes contain binding sites for NF-kappa B and thus their expression is controlled by the activity of NF-kappa B. ${ }^{13-15}$ It has been reported that NF-kappa B activity is negatively associated with $\mathrm{p} 38$ MAPK. In human melanoma cells, p38 MAPK suppresses NF-kappa B activity, which sensitizes melanoma cells to UV-, ribotoxic and radiomimetic chemicals-induced apoptosis. ${ }^{36}$ Although $5 \mathrm{~F}$ also reduces NF-kappa B activity and elevates the level of p38 in human colon cancer cells, the pathway linked these two molecules needs further study.

The decreased NF-kappa B activity, the reduction of $\mathrm{Bcl}-2$ and $\mathrm{Bcl}-\mathrm{xL}$ levels and the increased p38 and iNOS expression in the colon cancer cells treated with $5 \mathrm{~F}$ were in agreement with a significantly increase in the number of cell death and the amount of DNA fragmentation, a classic indicator of apoptosis. In order to further support our findings, we transfected the cells with $\mathrm{Bcl}-2$ or $\mathrm{Bcl}-$ $\mathrm{xL}$ genes and tested how these transfectants behaved in response to $5 \mathrm{~F}$ stimulation. After transfection with either $\mathrm{Bcl}-2$ or $\mathrm{Bcl}-\mathrm{xL}$, the cells showed a significant resistance to the $5 \mathrm{~F}$ treatment and the percentage of cell death was markedly different from those without $\mathrm{Bcl}-2$ or $\mathrm{Bcl}-\mathrm{xL}$ transfection. And also the activity of NF-kappa B was significantly higher in the cells with $\mathrm{Bcl}-2$ or $\mathrm{Bcl}-\mathrm{xL}$ genes. The current result may support the notion proposed by the previous reports that $\mathrm{Bcl}-2$ overexpression preserves 
or restores NF-kappa B and thus inhibits apoptosis. ${ }^{16,37}$ Furthermore, using a super-repressor of NF-kappa B, the cells with $\mathrm{Bcl}-2$ transfection re-gained their sensitivity to $5 \mathrm{~F}$ treatment. However, the cells with $\mathrm{Bcl}-\mathrm{xL}$ overexpression failed to have full recovery of their sensitivity to the drug stimulation. Therefore, it appears that the protective mechanism of $\mathrm{Bcl}-2$ and $\mathrm{Bcl}-\mathrm{xL}$ is different, to some extent, in colon cancer cells in response to $5 \mathrm{~F}$ stimulation, with the former being much more NF-kappa Bdependent than the latter. This is also one aspect that is different between $5 \mathrm{~F}$ and $\mathrm{UCN}-01$, whose treatment led to the similar level of NF-kappa B-dependent inhibition in the cells with the over-expression of either Bcl-2 or $\mathrm{Bcl}-\mathrm{xL}$. The mechanism accounting for the different levels of NF-kappa B-dependence in the cells with Bcl-2 and $\mathrm{Bcl}-\mathrm{xL}$ over-expression is worth further investigating.

Though both 5F and UCN-01 can offer anti-cancer effects probably via a similar mechanism, it is not clear what the advantage is of using $5 \mathrm{~F}$ in comparison to UCN-01. However, in vivo study of UCN-1 has shown that UCN01 can generate a number of side- or toxicological effects such as body weigh lose, leucopenia, bone marrow depletion and lymphoid tissue atrophy. ${ }^{38}$ Traditional Chinese herb medicine is usually tranquil. Nevertheless, further studies need to evaluate $5 \mathrm{~F}$ as an anti-cancer agent and also its side effects.

\section{Conclusion}

5F induced apoptosis in HT-29 cells and this apoptotic effect was associated with the high level of $\mathrm{p} 38$ and iNOS expression. The apoptotic effect of $5 \mathrm{~F}$ could be significantly offset by over-expression of either Bcl-2 or Bcl-xL. Bcl-2, and to the less extent, $\mathrm{Bcl}-\mathrm{xL}$, were able to increase the activity of NF-kappa B, which was a known anti-apoptotic molecule in human colon cancer cells. Inhibition of NFkappa $\mathrm{B}$ can restore the ability of $5 \mathrm{~F}$ to induce apoptosis. Therefore, apoptotic effect of $5 \mathrm{~F}$ on colon cancer cells is closely related to the activity of NF-kappa B.

\section{Acknowledgments}

The authors thank Dr. D. Brenner for the Ad5IkB and Ad5LacZ adenoviruses and Ms. S. Y. Chan and for her technical assistance.

\section{References}

1. Li J-H, He C-W, Liang N-C, Mo L-E, Zhang X. Effects of antitumor compounds isolated from Pteris semipinnata $\mathrm{L}$ on DNA topoisomerases and cell cycle of HL-60 cells. Acta Pharmacologica Sinica 1999; 20(6): 541-545.
2. Zhang X, Cui L, Nobutoshi T. The active constituents and antitumor action of Pteris semipinnata. Chinese Pharmaceutical Journal 1997; 32(1): 37-38.

3. Zhang X, Li JH, He CW, et al. Study on the diterpenoid constituents and anticancer action of Pteris semipinnata. Chinese Pharmaceutical Journal 1999; 34(8): 512-514.

4. Wang J-B, Liang N-C, Mo L-E. The effects of a diterpenoid compound $5 \mathrm{~F}$ isolated from pteris semipinnata $\mathrm{L}$ on the activity and expression of mitogen activated protein kinase in K562 cells. Chinese Pharmacological Bulletin 2002; 18(3): 294-297.

5. Wang J-B, Liang N-C, Mo L-E. The effects of a diterpenoid compound $5 \mathrm{~F}$ isolated from Pteris semipinnata L. on the expressions of several oncogenes of K562 cells. Chinese Pharmacological Bulletin 2002; 18(4): 418-421.

6. Chen GG, Lee JF, Wang SH, Chan UP, Ip PC, Lau WY. Apoptosis induced by activation of peroxisome-proliferator activated receptor-gamma is associated with Bcl-2 and NF-kappaB in human colon cancer. Life Sciences 2002; 70(22): 26312646.

7. Feinman R, Clarke KO, Harrison LE. Phenylbutyrate-induced apoptosis is associated with inactivation of NF-kappaB IN HT29 colon cancer cells. Cancer Chemotherapy E Pharmacology 2002; 49(1): 27-34.

8. Shao J, Fujiwara T, Kadowaki Y, et al. Overexpression of the wild-type p 53 gene inhibits NF-kappaB activity and synergizes with aspirin to induce apoptosis in human colon cancer cells. Oncogene 2000; 19(6): 726-736.

9. Mayo MW, Baldwin AS. The transcription factor NF-kappaB: Control of oncogenesis and cancer therapy resistance. Biochim Biophys Acta 2000; 1470: M55-M62.

10. Tamatani M, Mitsuda N, Matsuzaki H, et al. A pathway of neuronal apoptosis induced by hypoxia/reoxygenation: roles of nuclear factor-kappaB and Bcl-2. J Neurochem 2000; 75: 683693.

11. Tamatani M, Che YH, Matsuzaki $\mathrm{H}$, et al. Tumor necrosis factor induces $\mathrm{Bcl}-2$ and $\mathrm{Bcl}-\mathrm{x}$ expression through NFkappaB activation in primary hippocampal neurons. J Biol Chem 1999; 274: 8531-8538.

12. Kirito K, Watanabe T, Sawada K, Endo H, Ozawa K, Komatsu $\mathrm{N}$. Thrombopoietin regulates $\mathrm{Bcl}-\mathrm{xL}$ gene expression through Stat5 and phosphatidylinositol 3-kinase activation pathways. Journal of Biological Chemistry 2002; 277(10): 8329-8337.

13. Kurland JF, Kodym R, Story MD, Spurgers KB, McDonnell TJ, Meyn RE. NF-kappaB1 (p50) homodimers contribute to transcription of the bcl-2 oncogene. Journal of Biological Chemistry 2001; 276(48): 45380-45386.

14. Feuillard J, Schuhmacher M, Kohanna S, et al. Inducible loss of NF-kappaB activity is associated with apoptosis and Bcl-2 down-regulation in Epstein-Barr virus-transformed B lymphocytes. Blood 2000; 95: 2068-2075.

15. Khoshnan A, Tindell C, Laux I, Bae D, Bennett B, Nel AE. The NF-kappa B cascade is important in $\mathrm{Bcl}-\mathrm{xL}$ expression and for the anti-apoptotic effects of the CD28 receptor in primary human CD4 + lymphocytes. Journal of Immunology 2000; 165(4): 1743-1754.

16. Mandal M, Maggirwar SB, Sharma N, Kaufmann SH, Sun SC, Kumar R. Bcl-2 prevents CD95 (Fas/APO-1)-induced degradation of lamin $\mathrm{B}$ and poly(ADP-ribose) polymerase and restores the NF-kappaB signaling pathway. Journal of Biological Chemistry 1996; 271(48): 30354-30359.

17. Crawford MJ, Krishnamoorthy RR, Rudick VL, et al. Bcl-2 overexpression protects photooxidative stress-induced apoptosis of photoreceptor cells via NF-kappaB preservation. Biochemical E Biophysical Research Communications 2001; 281(5): 13041312 . 
18. Davis JN, Kucuk O, Djuric Z, Sarkar FH. Soy isoflavone supplementation in healthy men prevents NF-kappa B activation by TNF-alpha in blood lymphocytes. Free Radical Biology $\mathcal{E}$ Medicine 2001; 30(11): 1293-1302.

19. Jobin C, Panja A, Hellerbrand C, et al. Inhibition of proinflammatory molecule production by adenovirus-mediated expression of a nuclear factor kappaB super-repressor in human intestinal epithelial cells. Journal of Immunology 1998; 160(1): 410-418.

20. Xu Y, Bialik S, Jones BE, et al. NF-B inactivation converts a hepatocyte cell line TNF- response from proliferation to apoptosis. Am J Physiol 1998; 275: C1058-C1066.

21. Takahashi I, Kobayashi E, Nakano H, et al. Potent selective inhibition of 7-O-methyl UCN-01 against protein kinase C. Journal of Pharmacology \& Experimental Therapeutics 1990; 255(3): 1218-1221.

22. Seynaeve CM, Kazanietz MG, Blumberg PM, Sausville EA, Worland PJ. Differential inhibition of protein kinase C isozymes by UCN-01, a staurosporine analogue. Molecular Pharmacology 1994; 45(6): 1207-1214.

23. Dai Y, Yu C, Singh V, et al. Pharmacological inhibitors of the mitogen-activated protein kinase (MAPK) kinase/MAPK cascade interact synergistically with UCN-01 to induce mitochondrial dysfunction and apoptosis in human leukemia cells. Cancer Research 2001; 61(13): 5106-5115.

24. Usuda J, Saijo N, Fukuoka K, et al. Molecular determinants of UCN-01-induced growth inhibition in human lung cancer cells. International Journal of Cancer 2000; 85(2): 275-280.

25. Oshima T, Imada T, Nagashima Y, et al. Role of nitric oxide in human gastric cancer cells treated with 5 -fluorouracil. Oncology Reports 2001; 8(4): 847-849.

26. Millet A, Bettaieb A, Renaud F, et al. Influence of the nitric oxide donor glyceryl trinitrate on apoptotic pathways in human colon cancer cells. Gastroenterology 2002; 123(1): 235246.

27. Kwak JY, Han MK, Choi KS, et al. Cytokines secreted by lymphokine-activated killer cells induce endogenous nitric oxide synthesis and apoptosis in DLD-1 colon cancer cells. Cellular Immunology 2000; 203(2): 84-94.

28. Caivano M. Role of MAP kinase cascades in inducing arginine transporters and nitric oxide synthetase in RAW264 macrophages. FEBS Lett 1998; 429: 249-253.
29. Guan Z, Baier LD, Morrison AR. p38 mitogen-activated protein kinase down-regulates nitric oxide and up-regulates prostaglandin E2 biosynthesis stimulated by interleukin1beta. J Biol Chem 1997; 272: 8083-8089.

30. Cheng A, Chan SL, Milhavet O, Wang S, Mattson MP. p38 MAP kinase mediates nitric oxide-induced apoptosis of neural progenitor cells. Journal of Biological Chemistry 2001; 276(46): $43320-43327$.

31. Kim SJ, Hwang SG, Shin DY, Kang SS, Chun JS. p38 kinase regulates nitric oxide-induced apoptosis of articular chondrocytes by accumulating p53 via NFkappa B-dependent transcription and stabilization by serine 15 phosphorylation. Journal of Biological Chemistry 2002; 277(36): 33501-33508.

32. Murohara T, Parkinson SJ, Waldman SA, Lefer AM. Inhibition of nitric oxide biosynthesis promotes P-selectin expression in platelets. Role of protein kinase C. Arteriosclerosis Thrombosis $\mathcal{E}$ Vascular Biology 1995; 15(11): 2068-2075.

33. Garrouste F, Remacle-Bonnet M, Fauriat C, Marvaldi J, Luis J, Pommier G. Prevention of cytokine-induced apoptosis by insulin-like growth factor-I is independent of cell adhesion molecules in HT29-D4 colon carcinoma cells-evidence for a NF-kappaB-dependent survival mechanism. Cell Death $\mathcal{E}$ Differentiation 2002; 9(7): 768-779.

34. Wenzel U, Kuntz S, Brendel MD, Daniel H. Dietary flavone is a potent apoptosis inducer in human colon carcinoma cells. Cancer Research 2000; 60(14): 3823-3831.

35. Chang WC, Chapkin RS, Lupton JR. Predictive value of proliferation, differentiation and apoptosis as intermediate MAPKers for colon tumorigenesis. Carcinogenesis 1997; 18(4): 721-730.

36. Ivanov VN, Fodstad O, Ronai Z. Expression of ring fingerdeleted TRAF2 sensitizes metastatic melanoma cells to apoptosis via up-regulation of $\mathrm{p} 38$, TNFalpha and suppression of NF-kappaB activities. Oncogene 2001; 20(18): 2243-2253.

37. Crawford MJ, Krishnamoorthy RR, Rudick VL, et al. Bcl-2 overexpression protects photooxidative stress-induced apoptosis of photoreceptor cells via NF-kappaB preservation. Biochemical E Biophysical Research Communications 2001; 281(5): $1304-$ 1312.

38. Sausville EA, Lush RD, Headlee D, et al. Clinical pharmacology of UCN-01: Initial observations and comparison to preclinical models. Cancer Chemotherapy \& Pharmacology 1998; 42(Suppl): S54-S59. 